\title{
BERARDINELLI, Cleonice. Estudos camonianos. 2.ed. ampl. Rio de Janeiro: Nova Fronteira: Cátedra Padre Antônio Vieira, Instituto Camões, 2000.
}

Edgard Pereira Universidade Federal de Minas Gerais

ignatário de uma escrita de indiscutivel excelência no contexto do Renascimento europeu, Camões tem suscitado ao longo dos séculos inúmeras interlocuçòes, seja entre os escritores das mais variadas línguas (Schiller e Ezra Pound, por exemplo), seja entre os críticos seguidores das mais diversificadas vertentes. Alçado à dimensão de mito, pela indecisão fronteiriça entre a história e a ficsiao projetada no seu poema épico, é autor de uma produção poética multifacetada e fundadora. Na literatura portuguesa, são por demais conhecidas e admiradas as homenagens a ele prestadas por autores fundamentais, cujas intervençôes criativas reelaboram o seu extenso legado literário.
Cesário Verde, no poema "O sentimento dum ocidental", chama-lhe "épico de outrora" ascendendo num pilar, confrontando ao tom eufórico da exaltação épica das glórias passadas a descrição crua das misérias do presente, contrapondo aos "barões assinalados" as humildes "varinas". Fernando Pessoa, no limiar de sua projeção literária (revista $A$ águtia, 1912), refere-se ao surgir "breve do poeta (ou grupo de poetas) que deixaria a figura até então primacial de Camões em plano secundário" na famosa profecia sobre o "Supra-Camões", com a qual almeja se projetar na cultura européia. Jorge de Sena, não satisfeito em estudar-lhe profundamente a lírica e a épica, compõe o conto "Super flumina 
Babylonis", transformando-o em personagem admirável. Maria Gabriela Llansol promove os encontros dos tempos diversos, fazendo-o convergir para a época atual na pele de Luís Comuns, tendo como companheiros autores modernos e contemporâneos, tais como Fernando Pessoa (Aossê) e Jorge de Sena (Jorge Anés). Sabedores, como Llansol, de que é impossivel desatar o nó que liga, na literatura portuguesa, a água e os seus maiores textos, outros autores insistem em reler a sua obra: Miguel Torga, Fiama Hasse Brandão, Al Berto e muitos mais.

Um dos mais fecundos diálogos com a obra camoniana tem se realizado no Brasil, sob a forma de uma lúcida e apaixonada busca de interpretação e análise, através do discurso crítico de Cleonice Berardinelli, de que dão testemunho os recentes Estudos camonianos, vindos a lume. A autora, reverenciada no apagar das luzes do século em Paris e Portugal como um clos grandes nomes da lusofonia, dispensa apresentação, tendo o seu nome articulado a uma rica folla de trabalhos prestados aos estudos portugueses no Brasil e no exterior. Reedição e ampliação de livro de igual título publicado em 1973, o volume acrescenta aos sete ensaios originais outros onze, produzidos ao longo de mais de trinta anos e que se encontravam esparsos em anais, edições críticas, livro de ensaios e revistas especializadas. Constitui desta forma uma dádiva ao estudioso da obra de Camões, refletindo um olhar crítico e interdisciplinar poderosamente aparelhado, tendo como suporte várias tendências (entre outras, extraídas da crítica da recepção, genética, intertextual, estruturalista, formalista e de contextualização histórica). Tais instrumentais, entretanto, funcionam de maneira discreta, orquestrados por uma rigorosal conceituação filológica e não menos densa reflexão pessoal. À exceção dos dois textos agrupados no "Apêndice", elaborados de forma panorâmica, em função de sua natureza informativa (verbetes de dicionário) todos os outros ensaios procedem a uma densa investigaçào nos três gêneros (épico, lírico, dramático) em que se exercitou aquele que, num dos sonetos objeto de comprovação autoral, se apresenta di- 
zendo "De amor escrevo, de amor trato e vivo". Remexendo no extenso material deixado pelo autor de Os litsiadas, a pesquisadora brasileira constrói uma obra clássica, de referência obrigatória em futuras aproximações críticas.

Além do mérito de reunir material disperso em bibliografia de clificil acesso, alguns ensaios se revestem de uma natureza hermenêutica inaugural na área, como os que se debruçam sobre os paratextos da épica (o parecer do rei d. Sebastião c o do frei Bartolomeu Ferreira, indicado pela Inquisição), bem como os ensaio "Os excursos do Poeta n'Os lusiadas", interessado cm demonstrar a presença dialógica das várias vozes no pocma e o que se volta para a intricada questão do cânone cammoniano, "Introdução aos sonetos de Camões". Este, em especial, é fruto de clemorada pesquisa em raríssimas edições publicadas desde o século XVI ao século $\mathrm{XX}$, resultando em ambicioso projeto que discute amplamente opiniōes de inclusão ou cxclusão de textos e apresenta fontes fundamentais para a constituiçào do corpus lírico camoniano.
Como é sabido, este acervo lírico, tal como um rio se amplia à medida que se expande no espaço, recebendo afluentes, também se ampliou (por vezes de forma promíscua) largamente ao longo dos tempos, à mercê dos sucessivos editores que the acrescentavam sempre novos textos. Sem a pretensão de solucionar matéria sujeita a inúmeras controvérsias, constitui sem dúvida competente contribuiçào, reconhecida pelos mais renomados camonistas desde sua primeira publicação na prestigiosa edição crítica clos sonetos, no âmbito do quarto centenário da morte do Poeta - Sonetos de Camôes, (Lisbonne-Paris/Rio de Janeiro, Centre Culturel Portugais - Fund. Casa de Rui Barbosa, 1980).

Afora este minucioso inventário reflexivo sobre as várias ediçōes da lírica e os cancioneiros ou livros de mão em que sc fundamentaram, possibilitando o cotejo entre os critérios seletivos, fazendo o leitor participar do processo, outra substância anima estes estuclos: a sedução pela obra analisada, disseminada ao longo dos dezoito textos.

Entre as obsessões berardinellianas - a relação Pessoa/ 
Camões - o intertexto pessoano sido discípulo de Cleonice ou de com a produção camoniana é discípulos dela, de quem somos tema de outro instigante estudo. todos afetuosamente devedores, Que mais dizer senão que é um pelo muito que aprendemos e, livro extremamente necessário, parafraseando o Poeta, pelo oporturno e fascinante? Talvez muito que a amamos, de "um registrar o gosto e a honra de ter amor limpo e puro". 